\title{
Bioremoval of TI (I) by PVA-Immobilized Sulfate-Reducing Bacteria
}

\author{
Hongguo Zhang ${ }^{1 *}$, Meng $\mathrm{Li}^{1}$, Bo Pang ${ }^{1}$, Yingjuan $\mathrm{Wu}^{1}$, Yingqiang $\mathrm{Sun}^{3}$, \\ Diyun Chen ${ }^{1,3}$, Yongheng Chen ${ }^{2 * *}$ \\ ${ }^{1}$ School of Environmental Science and Engineering, Guangzhou University, \\ Guangzhou, 510006, China \\ ${ }^{2}$ Key Laboratory for Water Quality Security and Protection in the Pearl River Delta, \\ Ministry of Education and Guangdong Province, Guangzhou, 510006, China \\ ${ }^{3}$ Guangdong Provincial Key Laboratory of Radionuclide Pollution Control and Resources, \\ Guangzhou, 510006, China
}

Received: 13 November 2016

Accepted: 13 February 2017

\begin{abstract}
As scattered elements, thallium ( $\mathrm{Tl}$ ) contamination poses a significant threat to human health due its high toxicity. Sulfate-reducing bacteria (SRB) embedded in PVA-sodium alginate matrix was utilized as a novel bio-remover to remove $\mathrm{Tl}$ from aqueous solution. The effect of $\mathrm{pH}$, temperature, and initial $\mathrm{Tl}$ concentration on removal capacity of immobilized beads were studied and discussed in this work. The optimum bio-removal conditions were at $\mathrm{pH}$ value of 6 , temperature of $35^{\circ} \mathrm{C}$, and initial $\mathrm{Tl}$ concentration of $50 \mathrm{mg} . \mathrm{L}^{-1}$. The pseudo second-order model for $\mathrm{Tl}$ adsorption was applicable to all the removal data over the entire time range and intralayer diffusion was not the only rate-determining step. The bio-removal data conformed well to Langmuir isotherm model. Fourier transform infrared spectroscopy showed that sulfate reduction played an important role in $\mathrm{Tl}$ removal. The groups of carboxylate radical might be involved in sulfate reduction reaction.
\end{abstract}

Keywords: immobilized cells, sulfate-reducing bacteria, thallium, aqueous solution

\section{Introduction}

Thallium (Tl) and its compounds have been widely used in many respects of human life, including for medical purposes, imitation jewelry, low-temperature thermometers, ceramic semiconductor material, fireworks, and pigments [1]. As one of the 13 priority pollutant metals,

*e-mail: hgzhang@gzhu.edu.cn

**e-mail: cyhgzu@126.com
Tl was reported to be more toxic to human health than mercury, cadmium, lead, copper, or zinc [2]. It was a quite mobile metal and readily transported through aqueous routes into the environment due to the high solubility of its compounds. Tl was well known to have been responsible for many accidental, occupational, and therapeutic poisonings [3]. Its discharge and bioaccumulation in the environment has led to serious threats to human health or even causing death via drinking water and consuming vegetables, domestic birds, and animals bred in a Tlpolluted area, and inhaling Tl-bearing particles [4]. 
Concentrations in Tl-bearing wastewater have been observed to range from 1 to $1,600 \mu \mathrm{g} . \mathrm{L}^{-1}$ of $\mathrm{Tl}$. Considering its high environmental toxicity and undoubted risks to human health, Tl-bearing wastewater with $\mathrm{Tl}$ concentrations above $2 \mu \mathrm{g} . \mathrm{L}^{-1}$ have required being treated if discharged into surface water identified as a drinking water source [5-7]. Generally, Tl-bearing wastewater was treated with adsorption, oxidative precipitation, ion exchange, filtration, electrodialysis, and reverse osmosis for decontamination [7-9]. However, these processes were expensive and complex facilities or they led to secondary pollution [6]. For example, ion exchange was easily affected by environmental factors. Reverse osmosis was also an energy-condensed process. The restoration of membranes was hard after Tl removal [10]. Meanwhile, Tl-bearing wastewater usually was accompanied by high sulfate concentrations, which would affect the adsorption effect of activated alumina.

The bio-removal method was supposed to be a promising approach for heavy metal-bearing wastewater treatment. It was an economical and environmentally friendly approach since various natural materials, including bacteria, fungi, yeast, algae, etc., were utilized in the biosorption process [11-12]. Furthermore, the bioremoval process was able to remove $\mathrm{Tl}$ in dilute complex wastewaters from ppm to ppb level, which was suitable for treating Tl-polluted low-concentration complex solutions in a large scale, which was suitable for controlling the pollution of scattered elements in aqueous solution [13]. As a group of morphologically diverse and anaerobic microorganisms, sulfate-reducing bacteria (SRB) was a promising alternative to the traditional heavy metal remediation method. Sulfate was used as the terminal electron acceptor to produce hydrogen sulfide. Therefore, hydrogen sulfide was a promising option for achieving simultaneous removal of heavy metals and reduction of sulfate from wastewater through precipitation with heavy metals, especially $\mathrm{Cu}, \mathrm{Zn}$, and $\mathrm{Fe}$ [14]. Tl toxicity in the aqueous phase could be reduced through these mechanisms of SRB. The biological transformation process is described in Eqs. (1-2) [15].

$$
\begin{gathered}
2 \mathrm{CH}_{2} \mathrm{O}+\mathrm{SO}_{4}{ }^{2-} \rightarrow \mathrm{H}_{2} \mathrm{~S}+2 \mathrm{HCO}_{3}- \\
\left.\mathrm{H}_{2} \mathrm{~S}+\mathrm{Tl}^{+} \rightarrow \mathrm{Tl}_{2} \mathrm{~S}_{\mathrm{S}}\right)+2 \mathrm{H}^{+}
\end{gathered}
$$

...where $\mathrm{CH}_{2} \mathrm{O}$ represents the electron donor. However, ordinary anaerobic sludge existed several shortcomings of loosing floc structure, poor sedimentation performance, less unit microbial content, low activity, and bacterial species loss vulnerable to environmental factors, such as $\mathrm{pH}$ value and temperature [16].

Biological immobilization approaches had attracted great attention due to its high stability, high reactivity, and high processing efficiency [17-19]. Immobilized microspheres provided a suitable micro-environment for the SRB. It was reported that metal toxicity was controlled by immobilized SRB with strong resistance to metal ions by Min and Chai [20]. It was an ascendant technique that could be employed to remove high toxicity of heavy metals from aqueous solution. Sulfate-reducing bacteria immobilized on a fibrous slag (FS) was employed to recover cadmium through sulfide precipitates from low concentrations of cadmium-bearing water and, finally, the total amount of cadmium sulfide recovered $27.3 \mathrm{mg}$ per unit gram of FS [21]. The application of PVA in immobilizing SRB has received considerable attention due to its non-toxicity and low-cost properties compared with other supporting materials. PVA-immobilized SRB could enhance heavy metal removal and the resistance of SRB to heavy metal toxicity [22]. PVA-immobilized SRB granular removed up to $94.13 \%$ of sulfate, and up to $84.39 \%$ of manganese and ferrous ion in the process of treating synthetic acid mine drainage after five days[23]. PVA-immobilized SRB lowered leaching toxicity and achieved removal efficiencies of $76.3 \%, 95.6 \%, 100 \%$, and $91.2 \%$ for $\mathrm{Cu}, \mathrm{Zn}, \mathrm{Pb}$, and $\mathrm{Cd}$, respectively [24]. However, no studies have been carried out to investigate the application of PVA-immobilized SRB for Tl removal. The kinetics and isotherm model of Tl-polluted wastewater treatment through immobilized SRB have never been investigated.

The objective of this study was to investigate Tl bioremoval by PVA-immobilized SRB. The effect of $\mathrm{pH}$ value, temperature, and sulfate concentration of aqueous phase on $\mathrm{Tl}$ removal have been investigated in detail. The kinetics and mechanism of $\mathrm{Tl}$ removal by PVAimmobilized SRB was also studied thoroughly. The immobilized beads of SRB were characterized by fourier transform infrared (FTIR) spectroscopy to discuss the possible removal mechanism of PVA-immobilized SRB.

\section{Materials and Methods}

\section{Bacterial Source of SRB}

The SRB strain was isolated from an up-flow anaerobic sludge bed (UASB) which was used directly to treat acid mine drainage. The raw sludge was filtered and then fed with culture medium to form a mixture with $2 \%$ sludge. The culture medium was composed of (per liter of deionized water): $2.0 \mathrm{~g} \mathrm{MgSO}_{4}, 1.5 \mathrm{~g} \mathrm{KH}_{2} \mathrm{PO}_{4}, 0.1 \mathrm{~g} \mathrm{NH} 4 \mathrm{Cl}$, $0.5 \mathrm{~g}$ cysteine hydrochloride, $0.5\left(\mathrm{NH}_{4}\right)_{2} \mathrm{Fe}\left(\mathrm{SO}_{4}\right)_{2} \cdot 6 \mathrm{H}_{2} \mathrm{O}$, $1 \mathrm{~g}$ yeast extract, $0.1 \mathrm{~g} \mathrm{CaCl}_{2}, 0.3 \mathrm{~g}$ sodium citrate, $0.1 \mathrm{~g}$ ascorbic acid, and $2.0 \mathrm{~g}$ sodium lactate. The $\mathrm{pH}$ of the medium was adjusted to $7.0 \pm 0.1$ by $0.01 \mathrm{M} \mathrm{HCl}$ and 0.01 $\mathrm{M} \mathrm{NaOH}$. The mixture was placed in a $250 \mathrm{ml}$ anaerobic flask and charged with nitrogen gas for $10 \mathrm{~min}$ to remove dissolved oxygen (DO). Then it was sealed and transferred into an anaerobic workstation (YQX-II, Yuejing, China) for enrichment. $1 \mathrm{~mL}$ culture mixture was inoculated into the next flask with $100 \mathrm{~mL}$ culture solution. This step was repeated three times. The enrichment culture was diluted into different gradient concentrations and inoculated on solid culture medium with the above reagents by conventional spread plate techniques in anaerobic workstations for $48 \mathrm{~h}$. Black colonies were picked and 
then purified three times by streak dilution plating. When colonies growing on plates had the same appearance, they were collected and inoculated into another anaerobic flask with $100 \mathrm{~mL}$ culture solution for $48 \mathrm{~h}$ enrichment. The bacteria were collected and used for preparing PVAimmobilized SRB beads. All incubations were done at $30^{\circ} \mathrm{C}$ in the dark. Stock cultures were stored at $4^{\circ} \mathrm{C}$ and regularly transferred to fresh medium to maintain viability.

\section{Preparation of PVA-Immobilized SRB Beads}

Immobilization of biomass via entrapment was carried out as follows: the polyvinyl alcohol solution $(6 \%, \mathrm{w} / \mathrm{v})$, silica solution $(3 \%, \mathrm{w} / \mathrm{v})$, and sodium alginate solution $(0.5 \%, \mathrm{w} / \mathrm{v})$ were dissolved in deionized water and mixed thoroughly. Activated carbon solution (1\%,w/v) and SRB suspended solution $(35 \%, \mathrm{w} / \mathrm{v})$ were added into the colloid and mixed evenly at $40^{\circ} \mathrm{C}$. The alginate-biomass mixture was then extruded through a $10 \mathrm{ml}$ syringe into a $100 \mathrm{ml}$ $\mathrm{CaCl}_{2}(1 \%$, w/v) solution for polymerization. Each gram of the beads contained an average of $0.15 \mathrm{mg}$ of bacteria. The average diameter of the beads was approximate 2 $\mathrm{mm}$. Finally, immobilized beads were rinsed twice with sterile saline and stored at $4^{\circ} \mathrm{C}$ for further use [25].

\section{Chemicals}

The PVA (with 99.4-99.8\% saponification), $\mathrm{NaCl}$, sodium alginate, and $\mathrm{SiO}_{2}$ used in this study were supplied by Damao chemical reagent factory (analytical grade, Tianjin, China). A filter-sterilized solution of $\mathrm{TINO}_{3}$ (Guangdong Analysis and Testing Center, AR grade) was used as a source of $\mathrm{Tl}(\mathrm{I}) .0 .45 \mu \mathrm{m}$ microporous membrane filters were supplied by Laboratory Equipment Co., Ltd, China. All other chemicals used in this study were supplied by Zhiyuan Chemical Reagent Factory (analytical grade, Tianjin, China).

\section{Bio-Removal Experiments}

A series of experiments with variations of reaction conditions were conducted to investigate the effects of $\mathrm{pH}$ value, initial thallium concentration, and contact time, together with thermodynamics and kinetic studies on the $\mathrm{Tl}$ biosorption process.

Effect of temperature on $\mathrm{Tl}$ removal by the beads had been studied by using seven sets with three flasks for each set. These flasks were also autoclaved with $1 \mathrm{~g}$ beads (wet weight) being added into each flask containing $100 \mathrm{ml}$ of Tl-bearing solution. The original $\mathrm{pH}$ values were adjusted from $2.0,3.0,4.0,5.0,6.0$, and 7.0 to 8.0 with $0.01 \mathrm{M}$ $\mathrm{HCl}$ and $0.01 \mathrm{M} \mathrm{NaOH}$. All experiments were conducted at reaction temperature of $35^{\circ} \mathrm{C}, 150 \mathrm{rpm}$, initial $\mathrm{Tl}$ concentration of $20 \mathrm{mg} \mathrm{L}^{-1}$, and contact time of $24 \mathrm{~h}$. The temperature of the solution was controlled by shaking Baths (Jintan, SHZ-88, China).

In order to study the effect of initial $\mathrm{Tl}$ ion concentration and temperature on biosorption, together with thermodynamics and kinetic studies, experiments were conducted with various initial thallium ion concentrations from 1 to $100 \mathrm{mg} \mathrm{L}^{-1}$ at different temperatures of $30^{\circ} \mathrm{C}$, $35^{\circ} \mathrm{C}$, and $40^{\circ} \mathrm{C}, 150 \mathrm{rpm}$ and the $\mathrm{pH}$ value was adjusted to 7 by $0.01 \mathrm{M} \mathrm{NaOH}$ or $0.01 \mathrm{M} \mathrm{HCl}$. These flasks were also autoclaved with $1 \mathrm{~g}$ beads $(\mathrm{wd})$ being added into each flask containing $100 \mathrm{ml}$ of different concentrations of Tlbearing solution.

Two $\mathrm{ml}$ of samples from reaction were periodically collected after $24 \mathrm{~h}$ shaking. Samples were filtered with $0.45 \mu \mathrm{m}$ microporous membrane filters to estimate $\mathrm{Tl}$ concentration in the medium. Each $\mathrm{Tl}$ biosorption test was replicated three times, and the mean value and standard error were calculated to obtain reliable data. Tl concentration was determined using the flame atomic absorption method with a flame atomic absorption spectrometer (FAAS, TAS990, Beijing, China) [26].

Metal uptake capacity $q\left(\mathrm{mg} . \mathrm{g}^{-1}\right)$ was calculated by the following mass balance equation:

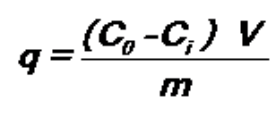

...where $C_{0}$ was the initial $\mathrm{Tl}$ concentration $\left(m g \cdot g^{-1}\right), C_{i}$ was the $\mathrm{Tl}$ concentration at equilibrium $\left(m g \cdot g^{-1}\right), V$ was the volume of solution (L), and $m$ was the weight of immobilized SRB (g).

\section{FTIR Analysis of Biomass}

Beads were dried at $40^{\circ} \mathrm{C}$, then grounded and sieved through a 200 mesh sieve for FTIR spectroscopy analysis (Tensor27, Bruker, Germany) equipped with a KBr beam splitter and a DTGS detector. Spectra of immobilized beads in absorbance mode between 4,000 and $400 \mathrm{~cm}^{-1}$ was recorded [27]. Background spectrum was recorded on a clean $\mathrm{ZnSe}$ spectral window.

\section{Results and Discussion}

\section{Effect of $\mathrm{pH}$ on Tl Removal}

In this work, $\mathrm{pH}$ values were varied to study the effect of $\mathrm{pH}$ value on biosorption of Tl. As shown in Fig. 1, Tl removal capacity increased from 118.77 to $229.92 \mathrm{mg} \mathrm{g}^{-1}$ bacteria when $\mathrm{pH}$ value increased from 2.0 to 6.0 , then it decreased from 226.47 to $211.88 \mathrm{mg} \mathrm{g}^{-1}$ bacteria when $\mathrm{pH}$ value further increased from 7.0 to 8.0 (Fig. 1). $\mathrm{pH}$ value played an important role in the bioremoval of heavy metal from aqueous solution. Hydrogen ions can vigorously compete with $\mathrm{Tl}(\mathrm{I})$ for the adsorption sites and the bacteria activity would be suppressed by low $\mathrm{pH}$ [28]. In addition, low $\mathrm{pH}$ value was not suitable for bacteria production and thus may cause a decline in metals adsorption. Along with the increase in $\mathrm{pH}$ value, $\mathrm{Tl}$ removal capacity gradually increased due to the increasing bacteria activity at a more adequate $\mathrm{pH}$ condition. However, high $\mathrm{pH}$ value was unfavorable for the growth of SRB since most SRB thrived at an optimum $\mathrm{pH}$, ranging from 6.0 to 7.0 [29]. In 


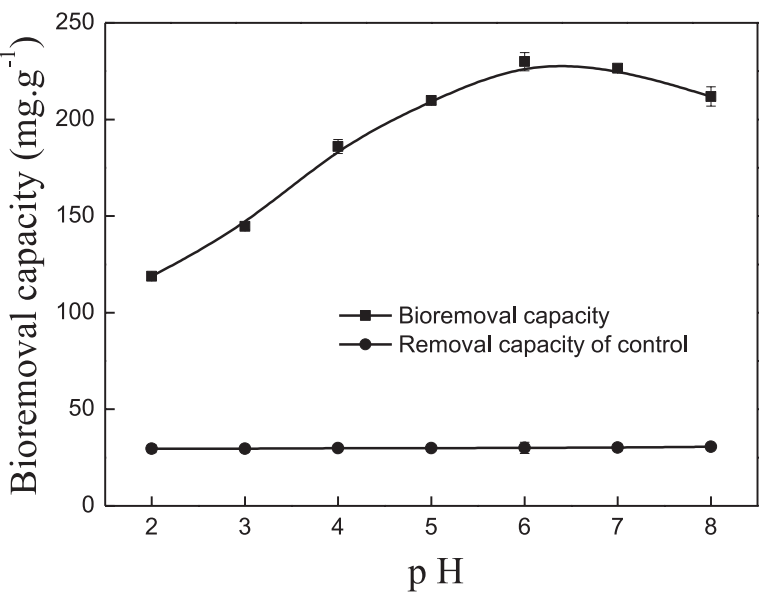

Fig. 1. Bioremoval capacity of $\mathrm{Tl}(\mathrm{I})$ at different $\mathrm{pH}$. Control was blank beads without cells. All experiments were performed in triplicate. Bars represent standard deviation.

our study, the optimum $\mathrm{pH}$ for $\mathrm{Tl}$ removal was around 6.0. The higher $\mathrm{pH}$ value led to a decrease in $\mathrm{Tl}$ removal, which was in line with the findings previously reported by Singh et al. [29-30]. Therefore, a pH value of 6 was suitable for Tl removal by the PVA-immobilized SRB beads.

\section{Effect of Initial Tl Concentration and Temperature on Tl Removal}

According to Fig. 2, when the initial $\mathrm{Tl}$ concentration increased from 25 to $50 \mathrm{mg} \mathrm{L}^{-1}$, the bio-removal capacity of $\mathrm{Tl}$ increased to $182.07,221.34$, and $207.91 \mathrm{mg} \mathrm{g}^{-1}$ at $30^{\circ} \mathrm{C}, 35^{\circ} \mathrm{C}$, and $40^{\circ} \mathrm{C}$, respectively. However, it is shown that $\mathrm{Tl}$ removal reached a plateau when initial $\mathrm{Tl}$ concentration increased to $100 \mathrm{mg} \mathrm{g}^{-1}$ (Fig. 2). Concentration difference is a driving force to overcome the mass transfer resistance between liquid and solid stages, leading to a higher $\mathrm{Tl}$ removal capacity at a larger initial $\mathrm{Tl}$ concentration. $\mathrm{Tl}$ ions may have more chances to

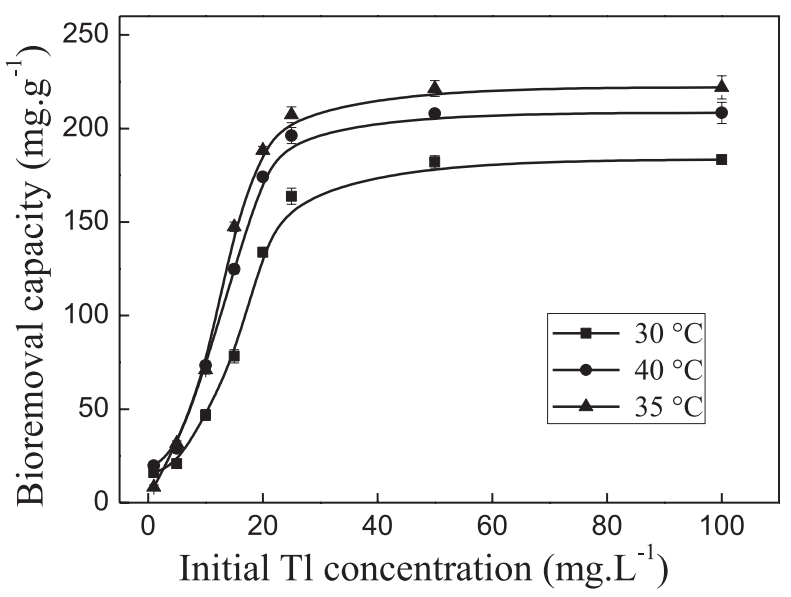

Fig. 2. Bioremoval capacity of $\mathrm{Tl}(\mathrm{I})$ at different initial $\mathrm{Tl}$ concentration and temperature. All experiments were performed in triplicate. Bars represent standard deviation. contact with adsorption sites when initial $\mathrm{Tl}$ concentration progressively increased. After full occupation of the active sites, $\mathrm{Tl}$ removal reached a peak level and did not increase when higher initial $\mathrm{Tl}$ concentration was used. It should be noted that hydrogen sulfide produced by the $\mathrm{SRB}$ could react with $\mathrm{Tl}(\mathrm{I})$ to form $\mathrm{Tl}_{2} \mathrm{~S}$ precipitate, which was favorable to $\mathrm{Tl}$ removal [15]. On the other hand, a high initial $\mathrm{Tl}$ concentration to an inhibitory level would restrain the activity of the SRB. In this study, the SRB were inhibited at the initial $\mathrm{Tl}$ concentration higher than $50 \mathrm{mg} / \mathrm{L}$, suggesting that the highest initial concentration of $\mathrm{Tl}$ should not be higher than this value.

As presented in Fig. 2, a higher removal capacity was observed at $35^{\circ} \mathrm{C}$ than at $30^{\circ} \mathrm{C}$ and $40^{\circ} \mathrm{C}$. The higher the temperature, the more active sites presented in immobilized beads due to the enhanced protonation and depronation rate of functional groups at higher temperature [31]. However, the activity of bacteria was slightly reduced at $40^{\circ} \mathrm{C}$, suggesting that the optimum temperature of this bacterial strain is $35^{\circ} \mathrm{C}$. This finding is in line with other studies in which the optimum growth temperature of most mesophilic SRB was reported in the range of $28-38^{\circ} \mathrm{C}$ [32]. Therefore, the optimum initial $\mathrm{Tl}$ concentration and temperature were $50.0 \mathrm{mg} \mathrm{L}^{-1}$ and $35^{\circ} \mathrm{C}$ for $\mathrm{Tl}$ removal from the aqueous solution by PVA-immobilized SRB.

\section{Bio-Removal Kinetic Studies}

Lagergren pseudo first-order (LPFO), Lagergren pseudo second-order (LPSO), and intraparticle diffusion model (IPD) were employed to model the sorption data over the entire time range. Relevant equations are generally expressed as [33]:

(1) LPFO:

$$
h\left(q_{e}-q_{t}\right)=h q_{e}-k, t
$$

(2) LPSO:

$$
\frac{t}{q_{t}}=\frac{1}{k_{2} q_{e}{ }^{2}}+\frac{t}{q_{e}}
$$

The correlation coefficient $\left(R^{2}\right)$ and average absolute percentage deviation $(\mathrm{D} \%)$ were applied to assess the kinetic mechanism of biosorption [34]. The D percentage values can be computed as:

$$
D \%=\frac{1}{N} \sum \sum_{i=1}^{N}\left|\frac{q_{e . e x p}-q_{e . c a l}}{q_{e . e x p}}\right| \times 100
$$

(3)IPD:

$$
q_{t}=k_{3} t^{1 / 2}+C
$$

...where $q_{e}$ and $q_{t}$ are the adsorption capacity $\left(\mathrm{mg} \mathrm{g}^{-1}\right)$ at equilibrium and time $t$, respectively; $k_{1}$ is LPFO rate constant $\left(\mathrm{min}^{-1}\right) ; k_{2}$ is LPSO rate constant $\left(\mathrm{mg} \mathrm{g}^{-1} \mathrm{~min}^{-1 / 2}\right)$; $k_{3}$ is IPD rate constant $\left(\mathrm{mg} \mathrm{g}^{-1} \mathrm{~min}^{-1 / 2}\right) ; q_{\text {e.cal }}$ is the removal 


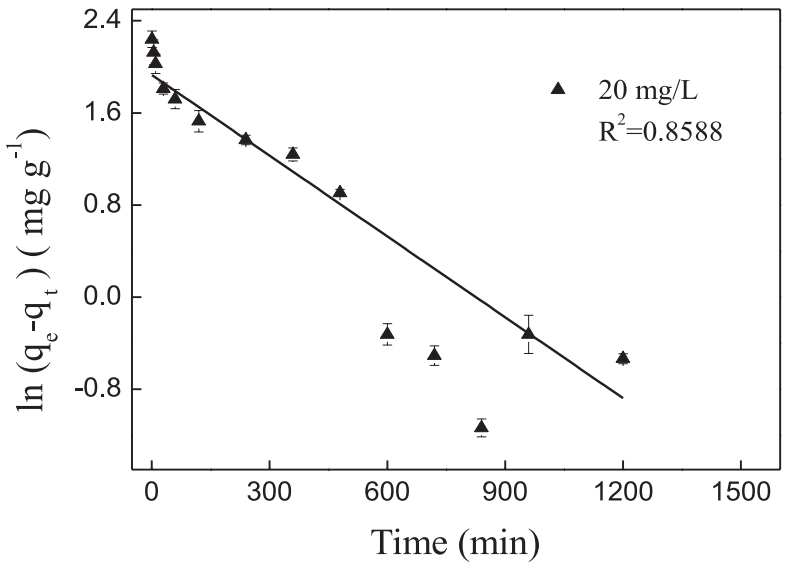

Fig. 3. Plot of $\ln \left(q_{e}-q_{t}\right)$ vs. $t$.

equilibrium capacity $\left(\mathrm{mg}^{-1} \mathrm{~g}^{-1}\right) ; q_{\text {e.exp }}$ is the actual capacity of removal equilibrium $\left(\mathrm{mg} \mathrm{g}^{-1}\right)$; $\mathrm{N}$ is the number of removal; and $\mathrm{C}$ is a constant.

Plotting to $\ln \left(q_{e}-q_{t}\right)$ versus time $t, t / q_{t}$ versus time $t$ and $q_{t}$ versus time $t^{1 / 2}$, respectively (Figs 3-5). The kinetic parameters were calculated by the slope and intercept of the fitting equation (Table 1). Fig. 3 shows the plot of $\ln \left(q_{e}-q_{t}\right)$ versus time t. The relationship was not linear over the entire time range $\left(R^{2}=0.8588\right)$, indicating that more than one mechanism is related in bio-removal. At the same time, LPSO had a higher $R^{2}$ and lower $\mathrm{D} \%$, which indicated that the LPSO model fit better to the experiment data than LPFO (Table 1).

Meanwhile, $q_{\text {e.cal }}$ was closer to $q_{\text {e.exp }}$ in LPSO than in LPFO, which confirmed that there were several mechanisms involved in the removal process [35].

The adsorption process can be divided into three phases: namely the film diffusion stage, the intralayer diffusion stage, and the dynamic equilibrium stage [36]. Generally, total removal rate was controlled by film diffusion, intralayer diffusion, or both. The kinetic data were fit with IPD in order to further study the bio-removal mechanism of immobilized SRB for Tl removal (Fig. 5a).

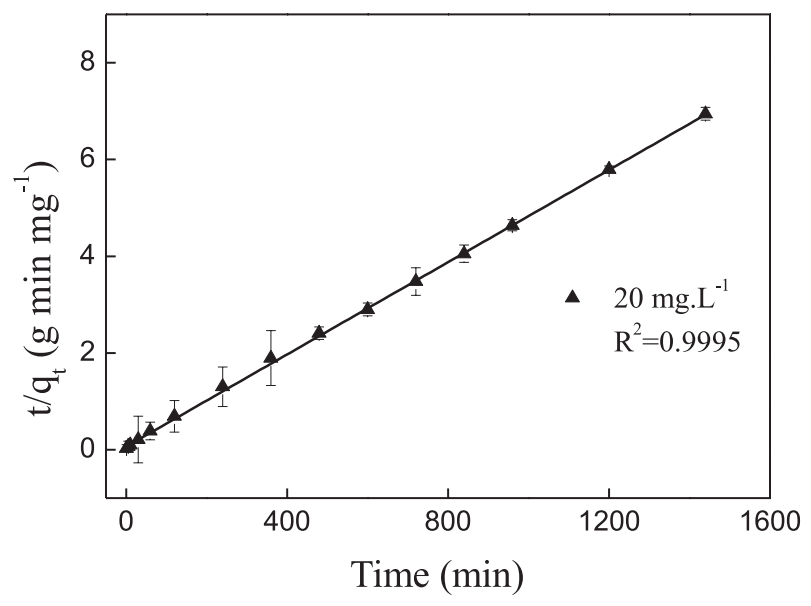

Fig. 4. Plot of $t / q$ vs. $t$.
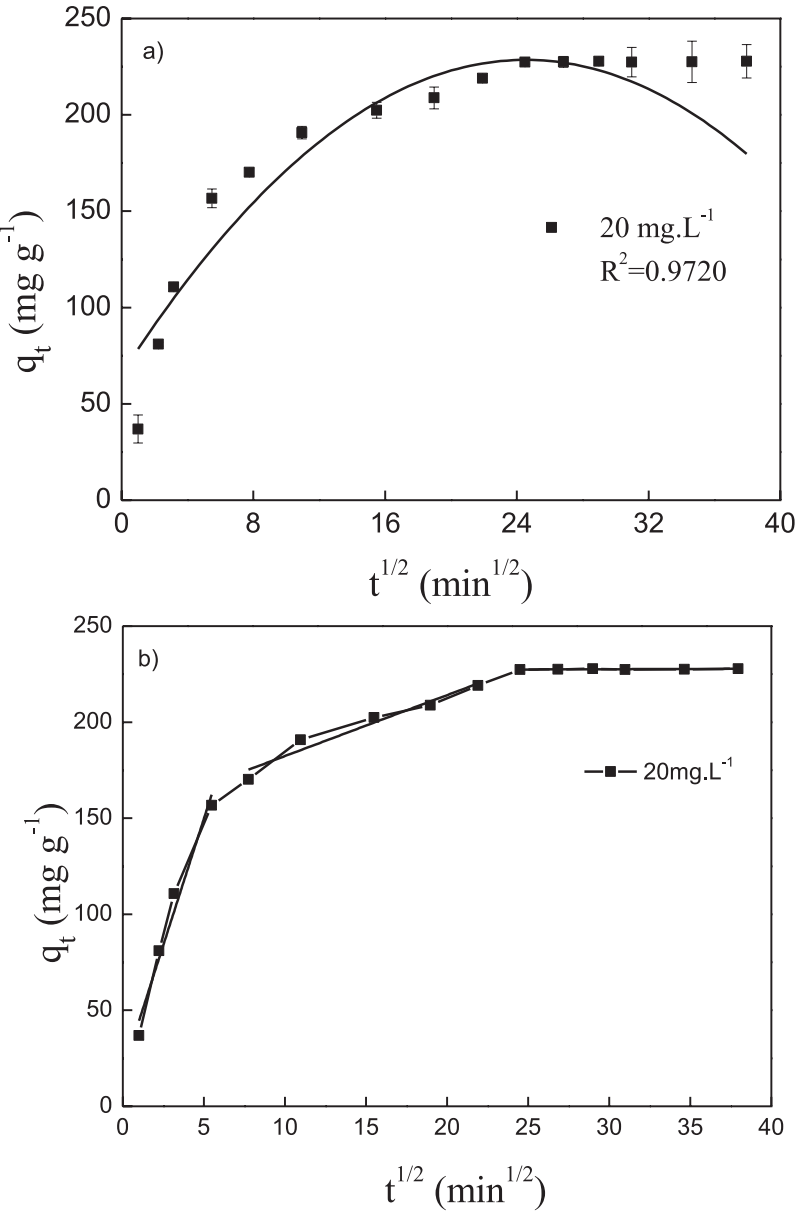

Fig. 5. Plot of $q_{t}$ : a) curve fitting, b) linear fitting.

The relationship between $q_{t}$ and $t^{1 / 2}$ was not linear over the whole time range, which indicated that there were several processes affecting bio-removal. The effect of film diffusion of the rate-determining step was also great according to Weber [37] (Fig. 5b).

Theoretically, if the intra-particle diffusion was the only rate-determining step, the initial rate parameter $\left(k_{3}\right)$ should be directly related to constant C. However, in this study the $k_{3}$ was far less than C (Table 1), which confirmed that intra-particle diffusion was not the only rate-determining step for $\mathrm{Tl}$ bio-removal by immobilized SRB.

\section{Bio-Removal Isotherm Model Studies}

The bio-removal isotherms indicated the reaction pathway of how adsorbents interact with adsorbates, which was described by Langmuir and Freundlich adsorption isotherms, respectively. Isotherm experimental studies were conducted with various initial $\mathrm{Tl}$ ion concentrations from 1 to $100 \mathrm{mg} \cdot \mathrm{L}^{-1}$ and analyzed by Freundlich and Langmuir isotherm models at different temperatures of 30,35 , and $40^{\circ} \mathrm{C}$. The correlation regression coefficients and constants of $\mathrm{Tl}$ biosorption are presented in Table 2 . 
Table 1. Kinetic Parameters of LPFO, LPSO, and IPD for Tl removal by immobilized SRB at fixed pH value of 7 with buffer solution at $35^{\circ} \mathrm{C}$.

\begin{tabular}{|c|c|c|c|c|c|c|c|c|}
\hline Equation & $\begin{array}{c}q_{\text {e.exp }} \\
\left(\mathrm{mg} \mathrm{g}^{-1}\right)\end{array}$ & $\begin{array}{c}q_{\text {e.cal }} \\
\left(\mathrm{mg} \mathrm{g}^{-1}\right)\end{array}$ & $\begin{array}{c}K_{1} \\
\left(\mathrm{~min}^{-1}\right)\end{array}$ & $\begin{array}{c}K_{2} \\
\left(\mathrm{mg} \mathrm{g}^{-1} \mathrm{~min}^{-1 / 2}\right)\end{array}$ & $\mathrm{R}^{2}$ & $\begin{array}{c}K_{3} \\
\left(\mathrm{mg} \mathrm{g}^{-1} \mathrm{~min}^{-1 / 2}\right)\end{array}$ & $\begin{array}{c}C \\
\left(\mathrm{mg} \mathrm{g}^{-1}\right)\end{array}$ & \begin{tabular}{c}
$\mathrm{D}^{\%}$ \\
\hline LPFO
\end{tabular} \\
\hline 207.3 & 8.2565 & $3.7 \times 10^{-3}$ & & 0.8588 & - & - & 96.02 \\
\hline LPSO & 207.3 & 212.77 & & $3.6 \times 10^{-4}$ & 0.9995 & - & - & 2.64 \\
\hline IPD & 207.3 & - & & - & 0.9720 & 1.5116 & 13.2960 & - \\
\hline
\end{tabular}

Table 2. Freundlich and Langmuir isotherm constants for Tl(I) adsorption on immobilized SRB at various temperatures.

\begin{tabular}{|c|c|c|c|c|c|c|c|}
\hline \multirow{2}{*}{$\mathrm{T}\left({ }^{\circ} \mathrm{C}\right)$} & \multicolumn{3}{|c|}{ Freundlich model } & \multicolumn{4}{c|}{ Langmuir model } \\
\cline { 2 - 8 } & $\mathrm{K}_{\mathrm{F}}$ & $1 / \mathrm{n}$ & $\mathrm{R}^{2}$ & $\mathrm{Q}_{\mathrm{m}}\left(\mathrm{mg} \mathrm{g}^{-1}\right)$ & $\mathrm{K}_{\mathrm{L}}\left(\mathrm{L} \mathrm{mg}^{-1}\right)$ & $\mathrm{R}_{\mathrm{L}}$ & $\mathrm{R}^{2}$ \\
\hline 30 & 15.08 & 0.6058 & 0.84 & 252.5253 & 0.03520 & $0.2212-0.9660$ & 0.82 \\
\hline 35 & 18.84 & 0.6134 & 0.86 & 259.7403 & 0.03423 & $0.2261-0.9669$ & 0.90 \\
\hline 40 & 11.18 & 0.7910 & 0.89 & 298.5075 & 0.02978 & $0.2514-0.9711$ & 0.88 \\
\hline
\end{tabular}

\section{Freundlich Isotherm Model}

The Freundlich isotherm model is an experimental model and generally described in the following equation [38]:

$$
\ln Q_{\text {eq }}=\ln K_{F}+\frac{1}{n} \ln C_{\text {eq }}
$$

...where $Q_{e q}$ is the amount of $\mathrm{Tl}(\mathrm{I})$ ions adsorbed at equilibrium (mg. $\left.\mathrm{g}^{-1}\right), C_{e q}$ is the equilibrium concentration of $\mathrm{Tl}$ ions (mg.L $\left.{ }^{-1}\right)$ in the solution, and $K_{F}$ and $n$ are Freundlich constants related to the adsorption capacity and indication of favorability, respectively. As shown in Fig. 6a, the Freundlich isotherm model did not fit the experimental result well. $K_{F}$ varied greatly with the increasing temperature (Table 2).

The adsorption intensity was favorable at higher temperature since all $n$ values were greater than 1 . However, the $1 / n$ values below 1 indicated a normal Freundlich isotherm, which implied that the adsorption process was more heterogeneous as $1 / n$ values gradually got closer to zero, while the $1 / n$ values above 1 was a symbol of cooperation adsorption [39]. The $1 / n$ values ranged from 0.61 to 0.79 in the study (Table 2), which indicated that the adsorption process for $\mathrm{Tl}(\mathrm{I})$ ion adsorption on immobilized SRB was heterogeneous. As presented in Table $2,35^{\circ} \mathrm{C}$ was deemed the suitable temperature for $\mathrm{Tl}$ removal by the beads, which got higher $\mathrm{K}_{\mathrm{F}}$ and lower $1 / n$ values. Table 2 showed that the Freundlich isotherm model also satisfactorily fitted the sorption data at the temperature of $35^{\circ} \mathrm{C}\left(R^{2}=0.86\right)$.

\section{Langmuir Isotherm Model}

The Langmuir isotherm model is a theoretical model for monolayer adsorption, which can be represented as [40]:

$$
\frac{C_{e q}}{Q_{e q}}=\frac{1}{K_{L} Q_{m}}+\frac{1}{Q_{m}} C_{e q}
$$
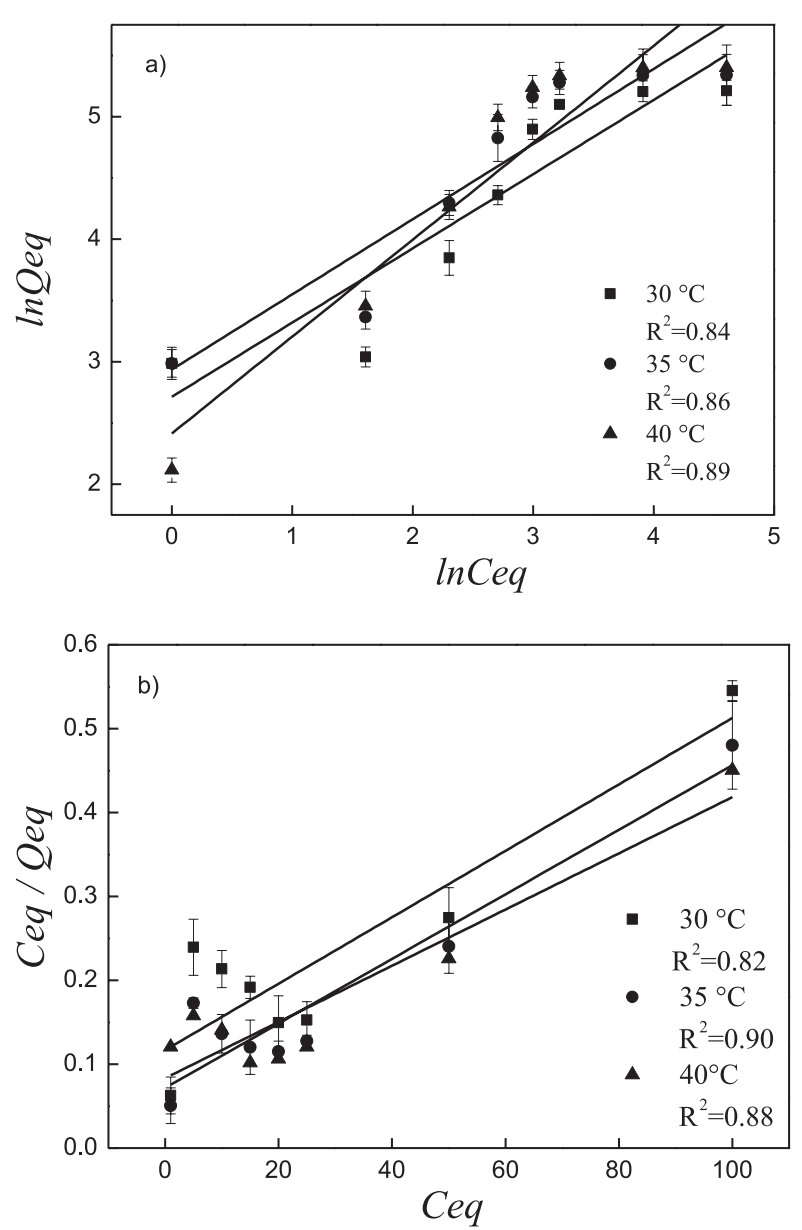

Fig. 6. Freundlich and Langmuir adsorption isotherm: a) Freundlich isotherm, b) Langmuir isotherm. 


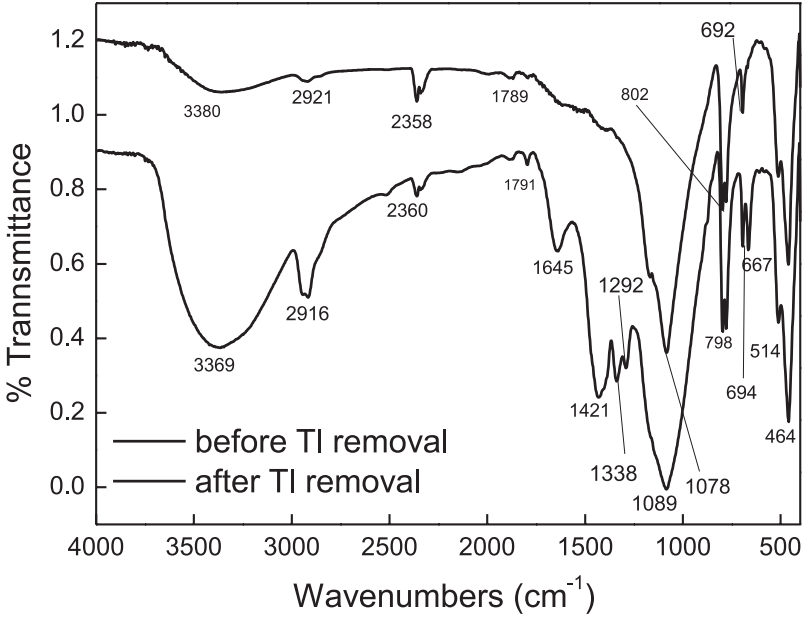

Fig. 7. FTIR spectra of immobilized beads.

$$
\mathrm{R}_{\mathrm{L}}=\frac{1}{1+\mathrm{K}_{\mathrm{L}} \mathrm{C}_{\mathrm{O}}}
$$

...where $Q_{m}$ is the maximum uptake capacity $\left(\mathrm{mg} \mathrm{g}^{-1}\right)$, $Q_{e q}$ is the amount of $\mathrm{Tl}(\mathrm{I})$ ions adsorbed at equilibrium (mg. $\left.\mathrm{g}^{-1}\right), C_{e q}$ is the equilibrium concentration of $\mathrm{Tl}$ ions (mg. $\mathrm{L}^{-1}$ ) in the solution, $C_{0}$ is the initial $\mathrm{Tl}$ concentration ( $\mathrm{mg} \mathrm{L}^{-1}$ ), and $K_{L}$ is the Langmuir adsorption intensity or coefficient related to the affinity between the binding sites of immobilized SRB and Tl(I) ions. $R_{L}$ is the equilibrium index or a dimensionless constant separation factor that can be used to assess whether the adsorption process is favorable; other symbols are as previously described [41]. Compared with the Freundlich isotherm model, the Langmuir model was more fit $\mathrm{Tl}$ removal date well over a concentration of 1-100 mg. $\mathrm{L}^{-1}$ (Table 2 and Fig. 6b). As represented in Table $2,35^{\circ} \mathrm{C}$ was the optimum temperature for $\mathrm{Tl}$ removal by the beads, the calculated Langmuir adsorption capacity, and the constant $\left(K_{L}\right)$ at $35^{\circ} \mathrm{C}$ was greater than the other temperatures.

\section{FTIR Analysis of Immobilized Beads}

FTIR analysis was used to characterize changes of functional groups before and after Tl bio-removal (Fig. 7). The intensity of the peak at $3,369 \mathrm{~cm}^{-1}$ was shifted to $3,380 \mathrm{~cm}^{-1}$ after $\mathrm{Tl}$ biosorption, which indicated that a hydrolysis reaction took place. The intensity of the peak shifted weakly from 2,916 to $2,921 \mathrm{~cm}^{-1}$ after bio-removal could be interpreted as the asymmetric and symmetric stretching vibrations of hydrocarbons in the immobilized SRB and partly bicarbonate radical disappearing. The intensity of the peak at 1,791 and $1,645 \mathrm{~cm}^{-1}$ turned weaker to $1,789 \mathrm{~cm}^{-1}$ may be interpreted as the carboxylate radical being affected by SRB [42]. The intensity of the peak at $1,089 \mathrm{~cm}^{-1}$ shifted to $1,078 \mathrm{~cm}^{-1}$, and the intensity of the peak from $1,292 \mathrm{~cm}^{-1}$ to $1,421 \mathrm{~cm}^{-1}$ disappeared, which indicated that the stretching vibration of sulfate happened. The intensity of the peak from $464 \mathrm{~cm}^{-1}$ to
$694 \mathrm{~cm}^{-1}$ transformed and parts of the peak disappeared, meaning that sulfate was reduced to sulfion by SRB, and sulfion would react with $\mathrm{Tl}(\mathrm{I})$ to form $\mathrm{Tl}_{2} \mathrm{~S}$ precipitation [43-44] (Fig. 7). Spectrum analysis of FTIR spectrum after $\mathrm{Tl}$ removal showed that sulfate reduction played an important role in $\mathrm{Tl}$ removal. The groups of carboxylate radical might be involved in sulfate reduction reaction.

\section{Conclusions}

In this work, SRB immobilized in PVA-sodium alginate matrix was utilized as a novel biological remover to remove $\mathrm{Tl}$ from aqueous solution. FTIR analysis was used to characterize changes of functional groups before and after Tl bio-removal. Sulfate reduction played key roles for Tl removal by PVA-immobilized SRB and the groups of carboxylate radical also might be involved in sulfate reduction reaction. The effect of $\mathrm{pH}$ value, temperature, and initial $\mathrm{Tl}$ concentration of the solution on $\mathrm{Tl}(\mathrm{I})$ removal process was investigated. The results proved that too high and too low $\mathrm{pH}$ value was not suitable for $\mathrm{Tl}$ removal by the beads of SRB and the suitable $\mathrm{pH}$ value was 6 . Also, biosorption of $\mathrm{Tl}$ increased with the increasing initial $\mathrm{Tl}$ concentration when initial $\mathrm{Tl}$ content was below $50 \mathrm{mg} . \mathrm{L}^{-1}$. The suitable bio-removal temperature was $35^{\circ} \mathrm{C}$. Tl(I) bio-removal by immobilized beads was well fitted by LPSO. The intra-particle diffusion was not the rate-determining step according to our removal kinetic analysis. The equilibrium of $\mathrm{Tl}$ biosorption was fairly well fitted by the Langmuir isotherm equation model.

\section{Acknowledgements}

This work was supported by the National Natural Science Foundation $(51208122,41372248,41173100)$, the New Technological Star Project of Pearl River (2011061), the Science and Technology Program of Guangzhou (2017), the High-Level University Construction Projects of Guangzhou City, and the Significant Innovation Project of Bureau Guangzhou Municipality (13XT02).

\section{References}

1. PETER A.L.J., VIRARAGHAVAN T. Thallium: a review of public health and environmental concerns. Environment international. 31, 493, 2005.

2. KEITH L.H., TELLIARD W.A. Priority Pollutants: I. A Perspective View. Environmental Science \& Technology. 13, 416, 1979.

3. MULKEY J.P., OEHME F.W. A review of thallium toxicity. Veterinary \& Human Toxicology. 35, 445, 1993.

4. XIAO T., FEI Y., LI S., ZHENG B., NING Z. Thallium pollution in China: A geo-environmental perspective. The Science of the total environment. 421-422, 51-8, 2012.

5. XIAO T., DAN B., GUHA J., ROULEAU A., HONG Y., ZHENG B. Groundwater-related thallium transfer processes and their impacts on the ecosystem: southwest 
Guizhou Province, China. Applied Geochemistry. 18, 675, 2003.

6. DAVIES M., FIGUEROA L., WILDEMAN T., BUCKNAM C. The Oxidative Precipitation of Thallium at Alkaline $\mathrm{pH}$ for Treatment of Mining Influenced Water. Mine Water \& the Environment. 35, 1, 2016.

7. PETER A.L., VIRARAGHAVAN T. Thallium: a review of public health and environmental concerns. Environment international. 31, 493, 2005.

8. CATHERINE W.B., TWIDWELL L.G. Removal of Thallium from Wastewater. Electrometallurgy \& Environmental Hydrometallurgy. 2, 1717, 2013.

9. TWIDWELL. L.G., WILLIAMS-BEAM C. Potential Technologies for Removing Thallium from Mine and Process Wastewater: An Abbreviated Annotation of the Literature. The European Journal of Mineral Processing and Environmental Protection. 2, 1303, 2002.

10. FU F., WANG Q. Removal of heavy metal ions from wastewaters: a review. Journal of environmental management. 92, 407, 2011.

11. WANG J., CHEN C. Biosorbents for heavy metals removal and their future. Biotechnology advances. 27, 195, 2009.

12. URÍK M., KRAMAROVÁ Z., ŠEVC J., ČERŇANSKÝ S., KALIŠ M., MEDVED' J., LITTERA P., KOLENČÍKK M., GARDOSOVA K. Biosorption and bioaccumulation of thallium(I) and its effect on growth of Neosartorya fischeri strain. Polish Journal of Environmental Studies. 19, 457, 2010.

13. WANG J. Biosorption of copper(II) by chemically modified biomass of Saccharomyces cerevisiae. Process Biochemistry. 37, 847, 2002.

14. HE B., YONG K., QUAN H., YANG H., JIAO S., YING F. Treatment of acid mine drainage by sulfate reducing bacteria with iron in bench scale runs. Bioresource technology. 128, 818, 2013.

15. MUELLER R.F. Microbially mediated thallium immobilization in bench scale systems. Mine Water and the Environment. 20, 17, 2001.

16. VALO R.J., HÄGGBLOM M.M., SALKINOJA-SALONEN M.S. Bioremediation of chlorophenol containing simulated ground water by immobilized bacteria. Water research. 24, 253, 1990.

17. SUN Y.M., HORNG C.Y., CHANG F.L., CHENG L.C., TIAN W.X. Biosorption of lead, Mercury, and cadmium ions by Aspergillus terreus immobilized in a natural matrix. Polish Journal of Microbiology. 59, 37, 2010.

18. KISIELEWSKAM.Ultrasonic stimulation of co-immobilized Saccharomyces cerevisiae cells and $\beta$-galactosidase enzyme for enhanced ethanol production from whey ultrafiltration permeate. Polish Journal of Environmental Studies. 21, 387, 2012.

19. DE-BASHAN L.E., BASHAN Y. Immobilized microalgae for removing pollutants: review of practical aspects. Bioresource technology. 101, 1611, 2010.

20. MIN X., CHAI L., ZHANG C., TAKASAKI Y., OKURA T. Control of metal toxicity, effluent COD and regeneration of gel beads by immobilized sulfate-reducing bacteria. Chemosphere. 72, 1086, 2008.

21. HAYASHI H., SYOGASE N., TSUNEDA S., HIRATA A., SASAKI H. Removal of Low Concentrated Cadmium Ions Using Fixed-bed Sulfate-Reducing Bioreactor with FS Carrier. Journal of Mmij. 119, 559, 2003.

22. HSU H.F., JHUO Y.S., KUMAR M., MA Y.S., LIN J.G. Simultaneous sulfate reduction and copper removal by a PVA-immobilized sulfate reducing bacterial culture. Bioresource technology. 101, 4354, 2010.
23. DI J., JIANG F., DAI N., ZHU Z. Characteristics in immobilization process of sulfate reducing bacteria sludge. Chinese Journal of Environmental Engineering. 9, 2227, 2015.

24. LI X., DAI L., ZHANG C., ZENG G., LIU Y., ZHOU C., XU W., WU Y., TANG X., LIU W. Enhanced biological stabilization of heavy metals in sediment using immobilized sulfate reducing bacteria beads with inner cohesive nutrient. Journal of hazardous materials. 2016.

25. SUN J., LIU J., LIU Y., LI Z., NAN J. Optimization of Entrapping Conditions of Nitrifying Bacteria and Selection of Entrapping Agent. Procedia Environmental Sciences. 8, 166, 2011.

26. RICE E.W., BAIRD R.B., EATON A.D., CLESCERI L. Standard methods for the examination of water and wastewater. American Public Health Association, American Water Works Association, Water Environment Federation: Washington, DC. 2012

27. JIN H., JI Z., LI Y., LIU M., YUAN J., XU C., HOU S. The preparation of a core/shell structure with alumina coated spherical silica powder. Colloids \& Surfaces A Physicochemical \& Engineering Aspects. 441, 170, 2014.

28. HAO O.J., CHEN J.M., HUANG L., BUGLASS R.L. Sulfate - reducing bacteria. Critical Reviews in Environmental Science and Technology. 26, 155, 1996.

29. SINGH R., KUMAR A., KIRROLIA A., KUMAR R. YADAV N., BISHNOI N.R., LOHCHAB R.K. Removal of sulphate, $\mathrm{COD}$ and $\mathrm{Cr}(\mathrm{VI})$ in simulated and real wastewater by sulphate reducing bacteria enrichment in small bioreactor and FTIR study. Bioresource technology. 102, 677, 2011.

30. REIS M.A.M., ALMEIDA J.S., LEMOS P.C., CARRONDO M.J.T. Effect of hydrogen sulfide on growth of sulfate reducing bacteria. Biotechnology \& Bioengineering. 40, 593, 1992.

31. BAJPAI J., SHRIVASTAVA R., BAJPAI A.K. Dynamic and equilibrium studies on adsorption of $\mathrm{Cr}(\mathrm{VI})$ ions onto binary bio-polymeric beads of cross linked alginate and gelatin. Colloids \& Surfaces A Physicochemical \& Engineering Aspects. 236, 81, 2004

32. WIDDEL F., HANSEN T.A., BALOWS A., TRUPER H.G., DWORKIN M., HARDER W., SCHLEIFER K.H. The dissimilatory sulfate- and sulfur-reducing bacteria: Springer Berlin Heidelberg; 1992.

33. PAN X., WANG J.Z.D. Biosorption of $\mathrm{Pb}$ (II) by Pleurotus ostreatus immobilized in calcium alginate gel. Process Biochemistry. 40, 2799, 2005.

34. LAUS R., COSTA T.G., SZPOGANICZ B., FÁVERE V.T. Adsorption and desorption of $\mathrm{Cu}(\mathrm{II}), \mathrm{Cd}(\mathrm{II})$ and $\mathrm{Pb}(\mathrm{II})$ ions using chitosan crosslinked with epichlorohydrin-triphosphate as the adsorbent. Journal of hazardous materials. 183, 233, 2010.

35. IRAM M., CHEN G., GUAN Y., ISHFAQ A., LIU H. Adsorption and magnetic removal of neutral red dye from aqueous solution using $\mathrm{Fe}_{3} \mathrm{O}_{4}$ hollow nanospheres. Journal of hazardous materials. 181, 1039, 2010.

36. ZHOU X., WEI J., LIU K., LIU N., ZHOU B. Adsorption of bisphenol A based on synergy between hydrogen bonding and hydrophobic interaction. Langmuir the Acs Journal of Surfaces \& Colloids. 30, 13861, 2014.

37. WEBER W.J., MORRIS J.C. Kinetics of Adsorption on Carbon From Solution. Asce Sanitary Engineering Division Journal. 1, 1, 1963.

38. HE Y.F., LING Z., WANG R.M., LI H.R., YAN W. Loess clay based copolymer for removing $\mathrm{Pb}$ (II) ions. Journal of hazardous materials. 227, 334, 2012. 
39. FYTIANOS K., VOUDRIAS E., KOKKALIS E. Sorption\&ndash; desorption behaviour of 2,4-dichlorophenol by marine sediments. Chemosphere. 40, 3, 2000.

40. LIU J., CHEN M., CHEN Z., YAN W. Effective removal of $\mathrm{Cu}$ (II) ions from aqueous solution by amino-functionalized magnetic nanoparticles. Journal of hazardous materials. 184, 392, 2010.

41. XU P., ZENG G.M., DAN L.H., CUI L., MEI H.Z., ZHEN W., NING J.L., CHAO H., GENG X.X. Adsorption of Pb(II) by iron oxide nanoparticles immobilized Phanerochaete chrysosporium : Equilibrium, kinetic, thermodynamic and mechanisms analysis. Chemical Engineering Journal. 203, 423, 2012.
42. MATHÉ C., WEILL C.O., MATTIOLI T.A., BERTHOMIEU C., HOUÉE-LEVIN C., TREMEY E., NIVIÈRE V. Assessing the role of the active-site cysteine ligand in the superoxide reductase from Desulfoarculus baarsii. Journal of Biological Chemistry. 282, 22207, 2007.

43. CAO J.J., JIANG Z.T., XIONG Z.H., YANG Y.N. Study on infrared spectra characteristics of fault particles of the sulfide deposit. Spectroscopy \& Spectral Analysis. 29, 956, 2009.

44. LANE M.D. Mid-infrared emission spectroscopy of sulfate and sulfate-bearing minerals $[\mathrm{J}]$. American Mineralogist, 92, 1, 2007. 